\title{
The Aspects of Policy Determination in the Formation of Autonomous Regions in Indonesia
}

\author{
Muhammad Barqah Prantama \\ Governmental Studies, Faculty of Social and Political Sciences, Universitas Brawijaya, Malang, Indonesia \\ http://dx.doi.org/10.18415/ijmmu.v8i9.2987
}

\begin{abstract}
This article examines the aspects that are determined in the formation of autonomous regions in Indonesia. As a country that adheres to the principle of decentralization, the policy of establishing an autonomous region is important and urgent in the context of the welfare of the people. The research method used in this article uses a literature search study. The results of the research are aspects used in the formation of autonomous regions are population criteria, economic capability criteria, regional potential criteria, financial capability criteria, socio-cultural criteria, socio-political criteria, area, defense and security, community welfare level, and span of control.
\end{abstract}

Keywords: Formation; Autonomous Regions; Policy

\section{Introduction}

The government system in Indonesia recognizes the existence of a central government and local government. The formation of regional government is based on the condition of the very wide territory of the State, covering various islands, the people have very diverse cultural backgrounds, and so on which results in the administration of government being difficult if everything is managed by the central government domiciled in the capital of the State.

Therefore, to manage the administration of government more effectively and efficiently in all corners of the country's territory, a regional government is formed to carry out government affairs or functions in the regions, especially those directly related to the needs of the people in the regions. Delegation of authority to the regions to administer and administer the regional government by the interests of the people is what is called decentralization. (Risal, M., 2016)

Theoretically, the granting of autonomy to regions is motivated by political and administrative goals to be achieved by the government of a country. The rationale of the political objective of regional autonomy is to create civil awareness and political maturity of the community through local government (Hendry, M., 1963).

The establishment of an autonomous region will soon be accompanied by the transfer of certain authorities or affairs. Theoretically, four central affairs cannot be delegated to the regions, namely defense and security affairs, foreign diplomatic affairs, judicial affairs, and financial affairs in the sense of printing money. This is because these matters are related to the sovereignty and existence of a country as well as the 
existence of the government as the main and final person in charge of providing protection and welfare for its people.

Apart from these functions, central government affairs can be decentralized to the regions. The main substance in the implementation of decentralization politics is how to optimally regulate the pattern of distribution of affairs or authority between the levels of government that is formed.

This concerns what authorities or affairs will still be carried out by the Central Government and what affairs will be decentralized to the regions. These arrangements will always refer to historical considerations, efficiency, and accountability in the administration of these affairs.

The targets for the establishment of new regional autonomy are (Haryati, D., 2012):

1) The achievement of synchronization and harmonization of central and regional laws and regulations;

2) Increasing cooperation between local governments;

3) Tthe establishment of effective, efficient, and accountable local government institutions; Fourth, increasing the capacity of professional and competent local government apparatus resource management;

4) Managed sources of funds and development financing in a transparent, accountable, and professional manner; and

5) The arrangement of new autonomous regions.

As a concept, decentralization has a very plural aspect of the review. But at least some decentralization concepts can be applied in the study of the expansion of new autonomous regions. As a country that adheres to the principle of decentralization, the policy of establishing an autonomous region is important and urgent in the context of the welfare of the people. This article examines the aspects that are determined in the formation of autonomous regions in Indonesia.

\section{Research Methods}

Research is a way to find answers to a problem, while the answers to these problems are in the form of research data obtained from the use of certain methods. The type of research used in this article is qualitative research with descriptive analysis. Qualitative research is a research method based on postpositivism philosophy. (Sugiono, 2008)

The results of qualitative research emphasize meaning rather than generalization. Qualitative research is aimed at describing and analyzing phenomena, events, social activities, attitudes and beliefs, perceptions, thoughts of people individually and in groups (Syaodih, N., 2013). Therefore, this article describes and analyzes aspects of the formation of autonomous regions in Indonesia.

\section{Research Result and Discussion}

The paradigm built in the process of implementing decentralization policies in the form of regional autonomy and regional expansion in Indonesia is always changing as a 'zig zag' pattern between decentralization and centralization (Jati, W. R., 2012). This can be seen in terms of policies as well as from the laws and regulations from the colonial era to the republic.

Three dominant laws were recorded, namely Decentraalisatiewet 1930, Wet op de Bestuurshervorming (Stb 1922/216), and Osamuseirei No. 27 of 1942. While in the republic period, there 
were 6 regional government laws, namely Law No. 1945, Law No. 22 of 1948, Law No. 1 of 1957, Law No. 18 of 1965, Law No. 5 of 1874, Law No. 22 of 1999, Law No. 32 of 2004, and finally Law No. 23 of 2014. Of the many Regional Government Laws, there are three dominant regional autonomy paradigms in reading the main substance of regional regulation by the state, namely centralized, federalists, and mixed.

The three paradigms were adapted to the socio-political constellation that developed at that time, where the characteristics of the central government regime also influenced the central view of the region (Jati, W. R., 2012). Autonomy in a political sense is defined as the right to self-regulate the internal interests of the region or its organization according to its law. (Marbun, B.N. 2007)

Globally, the issue of regional autonomy has emerged in many countries, mainly concerning the issue of the distribution of power as a real manifestation of democracy. In other words, regional autonomy as a manifestation of democracy is essentially an application of the concept of "area division of power" theory which divides power vertically in a country, giving rise to authority. On the one hand, the administration of government is carried out by the Central Government, while on the other hand, it is carried out by the Regional Government (Karim, A.G, 2003). The division of authority for the administration of government returns to the state government system adopted.

The form of adopting the principles of federalism in the form of regional autonomy in a unitary state because the unitary state itself does not recognize the concept of autonomy because all power is centralized in the government the center, the regions themselves are nothing more than the subordination of the government center. (Asshiddiqie, J., 2001)

The policy in the formation of autonomous regions in Indonesia takes into account several aspects regulated in the Republic of Indonesia Government Regulation Number 78 of 2007 concerning the requirements for the formation and criteria for the expansion, elimination, and merging of regions. The first aspect, the geographical condition of an area will determine the characteristics of the community, its livelihood, and culture. Population growth will lead to the expansion of settlements which have implications for the economic, political, administrative aspects, as well as the scope of the work area of the regional government. Changes in the area will occur rapidly along with population growth, social conditions, economy, transportation, and technology.

Thus, geographical and demographic conditions are quite dominant parameters in determining the pattern of government administration of a region. In this regard, the pattern and character of local government must be such that it allows local governments to be able to carry out their functions optimally both in the provision of public services (public service function), protecting the community (protective function), implementation of development (development function)., and able to adapt themselves to changes, dynamics, and developments in society and its strategic environment.

The existence of an autonomous region in principle must be able to improve the welfare of the community and improve services to the community. However, considerations of efficiency and effectiveness in service delivery are important factors that need to be considered in the formation of autonomous regions. In this case, the establishment of an autonomous region, especially a city area, should consider the balance between the area of the area and its population. Too many people in a narrow area can lead to the emergence of various social problems as a result of the lack of environmental carrying capacity. Likewise, too many residents can result in the inability of the local government to provide optimal services to its residents. Meanwhile, too small a population compared to the area will result in the provision of services that will require high costs so that it is not efficient (high cost).

Second, the aspect of economic capability in the formation of autonomous regions. The main consideration and objective of the establishment of a new autonomous region are to accelerate the achievement of the level of the economic welfare of the local community. Theoretically, to achieve the 
level of economic welfare, various efforts are needed concerning macro and micro-economic aspects. In the macroeconomic approach, it is explained that the pattern of economic growth in a region will be determined by the economic activities of various economic sectors in the region (Dumbusch \& Fisher, 1997), which consist of the household, private (business), and government sectors.

While the microeconomic approach explains that the resilience of economic actors is determined by their ability to manage various resources (resources) that are used efficiently in carrying out production. The estuary of the two approaches is the ability of a region to compete in its work during national and global economic struggles. Therefore, the analysis of socio-economic aspects will explain the macro and microeconomic conditions in the autonomous region that will be formed.

This is in line with the thinking of Dombusch \& Fischer (1997) that regional economic development will be analyzed from several variables, including the structure of the regional economy, economic competitiveness, the level of regional income calculated from its GRDP, regional comparative advantage, the potential for cooperation between region, local investment and investment that comes from outside, the culture of saving and consumption, local access to export markets, the convenience of local industries in obtaining production factors, as well as the strength of Regional Original Income and the amount of the Regional Expenditure Revenue Budget. The most important point in this regard is that the new region must have the adequate economic capacity to improve the welfare of its people and also the welfare of the wider community.

The third aspect is regional potential, the formation of an autonomous region one of which needs to consider regional potential criteria. Each region has various potentials that can be used as the basis for efforts to maintain the welfare standards that have been achieved by its citizens and can be developed to improve welfare or life at a better level. Regional potential itself is an estimate of revenue from the planned utilization of the availability of artificial resources, apparatus resources, and community resources that will be used to improve public services.

The current existence of these potentials (existing conditions) can be considered as the basic capital for the area to be formed. Likewise, regions of course have various other potentials which are still latent and still cannot be developed due to various obstacles. All of these potentials can be considered as regional resources that can be utilized to improve the welfare of the community. The fourth aspect is financial capability. The Gross Regional Domestic Product indicator is used to see the extent to which the region's ability (both government and society) is great in exploring and utilizing all resources or production factors (inputs) in the region into goods and services (output). The amount of the Gross Regional Domestic Product of a region also describes the competitiveness of a region compared to other regions.

The Gross Regional Domestic Product figures also provide an indication of the extent to which economic activity occurring in an area in a certain period has generated additional income for the community (Susanti et al, 1995). This indication is implied from output growth because basically economic activity is a process of using production factors to produce goods and services (output) which in turn will result in a flow of remuneration for production factors owned by the community. Thus the output growth is expected to increase the income of the community as the owner of these production factors.

Fifth is the socio-cultural criteria. The desire to form an autonomous region is a reflection of the increasing public awareness of their rights as citizens (citizens) that need to be accommodated proportionally. This desire can arise due to historical (historical) background and socio-cultural factors. From historical factors, the desire for the formation of a new autonomous region can arise because the area has a historical background that is considered different from the parent region. Pride in the history of the past and the desire to preserve or re-enact the glory of the past are often the main reasons for the desire of the people. Therefore, from the historical aspect, it is necessary to study further how the history of a region in the past, the relevance of these historical aspects to the formation of new autonomous regions, and the extent to which history affects people's lives today. 
Socio-cultural criteria in the formation of autonomous regions, in this case, will be studied through three indicators and four sub-indicators. The indicators used are 1) indicators of places of worship, with sub-indicators of the ratio of religious facilities per 10,000 residents, 2) indicators of places for social institutions with sub-indicators of the ratio of performing arts venues per 10,000 residents, and the ratio of social institutions per 10,000 residents, and 3) indicators of sports facilities with a sub-indicator of the ratio of sports field facilities per 10,000 populations. The three indicators are used with the assumption that the socio-cultural aspects of the community in the area are actualized through various forms of real activities such as religious activities, artistic activities, sports, and other activities. Therefore, the availability of various socio-cultural facilities is considered to reflect the extent of the socio-cultural conditions of the community in the area to be formed. These indicators and sub-indicators all reflect two things.

The socio-political aspect of the desire to form an autonomous region can be traced from the sociopolitical dynamics that occur in the area. This is mainly related to the desire of the community to have wider authority in the administration of government so that the government is more democratic, freer, and more able to accommodate the interests of the local community. Socio-political dynamics in an area can be read from the extent of the role of socio-political organizations in the area in channeling the aspirations of the community.

This is done to uncover various questions such as whether the desire for the formation of a new autonomous region has been the desire of the whole community or only the desire of a few political elites in the region, whether all political elites in the region have the same vision in the formation of an autonomous region, and whether socio-political organizations existing in the area are ready and provide support for the formation of a new autonomous region separate from the parent region.

The study on socio-political criteria, in this case, is centered on two indicators, namely 1) indicators of public participation in politics with sub-indicators of the ratio of the population participating in the General Election to the number of people with voting rights, and 2) indicators of community organizations with sub-indicators of the number of community organizations.

The seventh aspect in the formation of an autonomous region is the area of the region. No single government of a country with a large area can determine its policies or implement its policies and programs effectively and efficiently through a centralized system (Bowman \& Hampton, 1983). This view forms the basis for the need for delegating or handing over part of the authority of the Central Government to organizations or units outside the central government itself, both in political and administrative connotations.

The transfer or delegation of power or authority can take the form of devolution, deconcentration, delegation, or privatization. Eighth is the aspect of defense and security. Defense and security aspects are considered because one of the functions of local government is a protective function, namely protecting the community from various disturbances and threats that can create a sense of insecurity for the community.

The ninth aspect is the level of community welfare, the existence of a new autonomous region, public access to local government services will be faster, the quality of service will be better, and the welfare of the community, in general, will increase. In the future era, where the government only acts as a facilitator, an effective number of government employees is needed. (Osbome \& Gaebler, 1997)

And the last aspect is the span of control. The formation of new autonomous regions has consequences for the need for institutions that will accommodate various local government activities, the need for employees who will carry out government tasks and services, and the need for government facilities and infrastructure that will be used to facilitate the implementation of government tasks and services. In this case, what also needs to be considered is the availability of land that can be used to build or develop the various new infrastructure needed by autonomous regions. 
The number of sub-districts and the distance between sub-districts and villages to the center of government is one of the benchmarks that must be considered in the formation of new autonomous regions. This is mainly related to the span of control that will determine community access to local government services. The formation of new autonomous regions should be able to shorten the distance between service centers and their coverage areas, thereby shortening the span of government control.

Likewise, the establishment of new autonomous regions should be able to shorten the travel time of the community in accessing various types of local government services. In this regard, the number of villages in each sub-district needs to be linked to the total population. This needs to be done to determine the ratio between the number of employees and the number of residents who must be served which will then determine the scope of service and the level of service effectiveness.

\section{Conclusion and Suggestion}

The policy in the formation of autonomous regions in Indonesia takes into account several aspects regulated in the Republic of Indonesia Government Regulation Number 78 of 2007 concerning the requirements for the formation and criteria for the expansion, elimination, and merging of regions. The aspects used in the formation of autonomous regions are population criteria, economic capability criteria, regional potential criteria, financial capability criteria, socio-cultural criteria, socio-political criteria, area, defense and security, community welfare level, and span of control.

\section{References}

Asshiddiqie, J. 2001. Pengantar Pemikiran UUD Negara Kesatuan RI. Jakarta: The Habibie Center.

Haryati, D. (2012). Pembentukan 19 Daerah Otonom Baru. Info Singkat Pemerintahan Dalam Negeri, Vol, No 07/1/P3DI/April2012.

Henry, M. (1963). Democracy, Decentralization. Jogjakarta: BPFE.

Jati, W.R. 2012. Inkonsistensi Paradigma Otonomi Daerah di Indonesia: Dilema Sentraliisasi atau Desentralisasi. Jurnal Konstitusi, Vol. 9, No. 4, Desember 2012. DOI: https://doi.org/10.31078/jk\%25x

Marbun, B.N. 2007. Kamus Politik. Jakarta: Pustaka Sinar Harapan.

Republic of Indonesia Government Regulation Number 78 of 2007.

Risal, M. (2016). Kearifan Lokal Dalam Pembentukan Daerah Otonomi Baru di Era Otonomi Daerah (Studi Kasus: Kearifan Lokal di Daerah Apau Kayan Kabupaten Malinau). Jurnal Administrative Reform, Bol. 4 No 2, April - Juni 2016. DOI: http://dx.doi.org/10.52239/jar.v4i2.597

Sugiono. 2008. Educational Research Methods. (Cet. 6). Bandung: Alfabeta.

Syaodih, N. 2013. Educational Research Methods. Bandung: Remaja Resdakarya.

\section{Copyrights}

Copyright for this article is retained by the author(s), with first publication rights granted to the journal.

This is an open-access article distributed under the terms and conditions of the Creative Commons Attribution license (http://creativecommons.org/licenses/by/4.0/). 